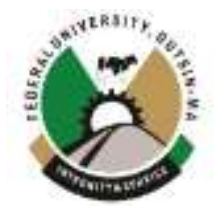

\title{
ASSESSMENT OF TOMATO FARMERS' IRRIGATION PRACTICE IN PAMPAIDA MILLENNIUM VILLAGE, IKARA LOCAL GOVERNMENT AREA, KADUNA STATE, NIGERIA
}

\author{
${ }^{* 1}$ Ahmed, A., ${ }^{2}$ Oyebode, M. A., ${ }^{2}$ Igbadun, H. E. and ${ }^{3}$ Oiganji, E. \\ ${ }^{1}$ Bauchi State College of Agriculture, Bauchi, Nigeria \\ ${ }^{2}$ Department of Agricultural Engineering, Ahmadu Bello University \\ ${ }^{3}$ Department of Crop production, University of Jos, Nigeria
}

*Corresponding author email: ahmedhabu@gmail.com +2348023146832

\begin{abstract}
This study was conducted in Pampaida Millennium Village (PMV), Ikara Local Government Area of Kaduna State, Nigeria; during the 2009/2010 dry season to assess Tomato farmer's irrigation water management practice using furrow irrigation. A total of 7 tomato farmers were selected out of 45 farmers for the assessment exercise. Soil moisture content was monitored throughout the growing season using gypsum blocks. The hydraulic performance of the farmer's plots were assessed. Similarly, the seasonal water requirement and irrigation schedule for the irrigated tomato were also determined. The results showed that the highest Application Efficiency, Distribution Uniformity and Adequacy of irrigation were obtained in plots T6 (92\%), T3 $(89 \%)$ and $\mathrm{T} 7(92 \%)$ respectively. The least AE, DU and AI were obtained in plot T1 as $74 \%, 72 \%$ and $63 \%$ respectively. The yield obtained ranged from $11.6 \mathrm{t} / \mathrm{ha}$ to $22.3 \mathrm{t} / \mathrm{ha}$. The least yield was obtained in plot $\mathrm{T} 2$; while the highest yield was obtained in plot T1. All the assessed farmers maintained a 4day irrigation interval throughout the growing season. The highest crop water use efficiency (CWUE) of $62.80 \mathrm{~kg} / \mathrm{ha}-\mathrm{mm}$ was obtained in plot T1, with a corresponding crop water use (CWU) of $355 \mathrm{~mm} / \mathrm{season}$. The least CWUE was obtained in plot T2 $(41.6 \mathrm{~kg} / \mathrm{ha}-\mathrm{mm})$ with a corresponding CWU of $399 \mathrm{~mm} / \mathrm{season}$. Based on the results obtained it can be deduced that plot T1 gives best results among the assessed farmers' plots in terms of crop water use efficiency and effectiveness of irrigation, which maximizes net farm profit.
\end{abstract}

Keywords: Surface irrigation, water use efficiency, performance evaluation, Application Efficiency

\section{INTRODUCTION}

Agriculture is the major source of employment and livelihood for majority of Nigeria's population. The sector employs over two-thirds of the Nigerian labour force, accounting for about $35 \%$ of the Gross Domestic Product (GDP) (Fagade, 1997). The optimum use of irrigation water is a fundamental stride in attaining sustainable Agriculture. Optimal level use of irrigation water for a particular situation is that which produces the maximum profit per unit of water applied. One of the major setbacks to agricultural production in Nigeria has been the non availability and inefficient distribution of water (Phillip, 1990). Water as an agricultural source was found to be limiting. The declining water resources and growing competition for fresh water has continued to reduce its availability for irrigation in arid and semi arid regions. Feeding a planet of 8 billion by 2030 will require producing more food with less water and through improved water efficiency in agriculture (Qamar and Tyem, 1994; World Bank, 2011).

FAO (1989) outlined the problems irrigated agriculture may face in the future. One of the major concerns is the generally poor efficiency with which water resources have been used for irrigation. A relatively safe estimate is that 40 percent or more of the water diverted for irrigation is wasted at the farm level through either deep percolation or surface runoff. The need to meet the World's growing demand for food requires increased crop production from less water (FAO, 2002; Kirda 2002). But under the semi arid conditions of Nigeria, water is by far the major constraint to crop production (Graham et al., 1995). Therefore, techniques are needed to increase water use efficiency, which includes water management principles (Tariq and Usman, 2009).

The Pampaida Millennium Village (PMV) comprises of 28 settlements with a population of about 5,666 people (NPC, 2006). The community is a cluster of agrarian settlements that depend on rain fed agriculture as well as on smallholder traditional irrigation farming for their livelihood. Their livelihoods are mainly based on small-scale agriculture giving the region a characteristic presence of agricultural crops, trees and livestock.

Tomato, being one of the high value economic crops grown by farmers within the cluster, is actually grown two times under dry season irrigation farming. The farmers depend directly or indirectly on tomato production and sales as their means of livelihood during dry season period. However, in recent times, dry season farming in Pampaida is becoming increasingly difficult due to fluctuating weather conditions. The underground recharge has become unreliable, which also makes it difficult for the farmers to plan their irrigation schedules effectively and successfully (Sanchez et al., 2009), it has become necessary for the farmers in Pampaida MVP to find ways of conserving the scarce natural resource so as to benefit from the efficient and effective utilization of the irrigation water. It is widely recognized that the traditional method of production techniques presently practice, do not put into consideration the amount of water applied to the crop, how frequent and how much water 
could be used by the crop in Pampaida, hence, the need for this research.

\section{MATERIALS AND METHOD}

The study was carried out in Pampaida Millennium Village (PMV) site located at Saulawa District in Ikara Local
Government Area of Kaduna State, during 2009/2010 dry season farming. The PMV site is about $60 \mathrm{~km}$ from Zaria city of Kaduna State. The topography of the area is of gentle slopes gradually sloping downwards into a river.Pampaida is located on latitude $11^{0} 29 " \mathrm{~N}$ and longitude $8^{0} 15^{\prime \prime} \mathrm{E}$. The irrigation method practiced is mainly furrow irrigation with furrow lengths of between 3 to $10 \mathrm{~m}$ (Sanchez et. al .,2009).

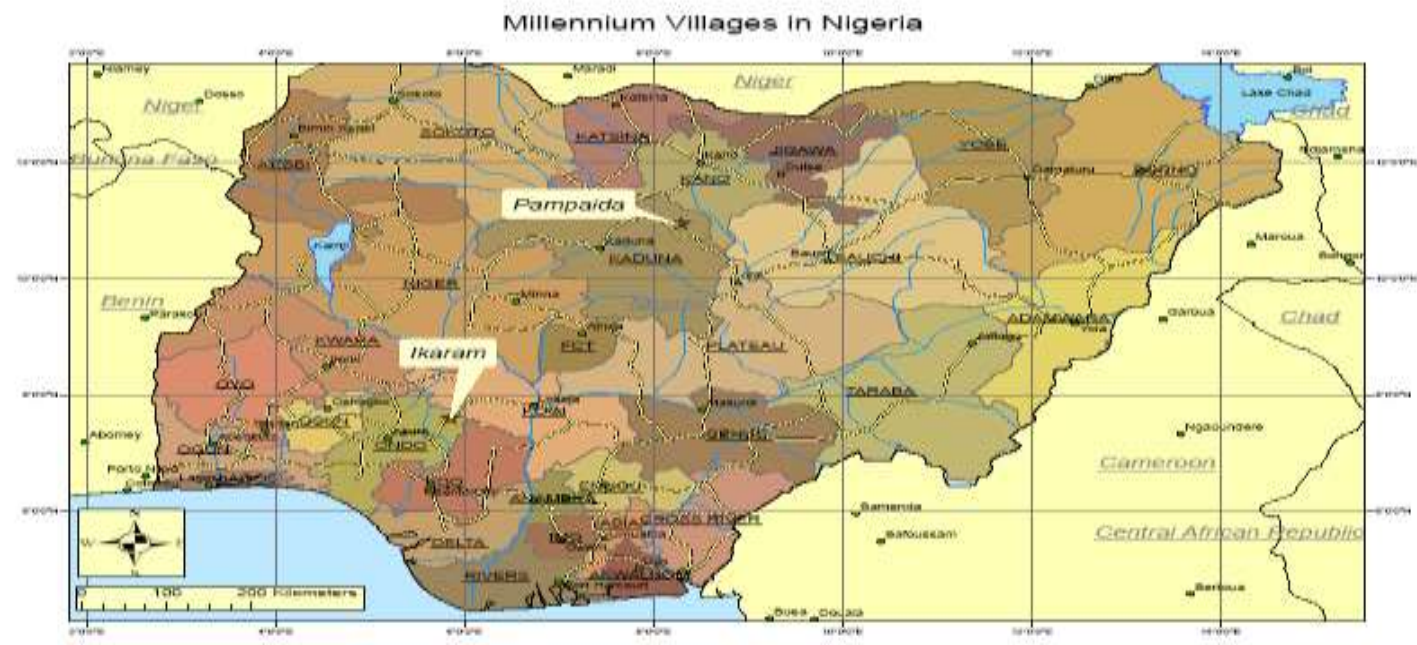

Figure 1. Map of Nigeria showing location of Pampaida (PMV)

The climate of Pampaida is marked by both wet and dry season which can be sub-divided into three, namely; a cool dry season from October to February; a hot dry season from March to May, and a warm wet season from June to September. The raining season usually starts from late May and ends in early October. Mean monthly temperatures range from $30^{\circ} \mathrm{C}$ to $39^{\circ} \mathrm{C}$, and a mean relative humidity ranging from $30-70 \%$ annually. Irrigation is normally practiced in the months of November to May, which are the driest months in the year.The PMV1 area has an annual rainfall ranging from $800-1,050 \mathrm{~mm}$ per annum. (Sanchez et.al., 2009)

\section{Soil Physical Properties}

Table 1: General characteristics of the selected farmer's plots

\begin{tabular}{cccc}
\hline Plot & $\begin{array}{c}\text { Area of farms } \\
\left(\mathbf{m}^{\mathbf{2}}\right)\end{array}$ & $\begin{array}{c}\text { Area } \\
(\mathbf{h a})\end{array}$ & Transplanting date \\
\hline $\mathrm{T} 1$ & $48 \times 47$ & 0.226 & $06-03-10$ \\
$\mathrm{~T} 2$ & $145 \times 46$ & 0.207 & $10-03-10$ \\
$\mathrm{~T} 3$ & $50 \times 50$ & 0.252 & $18-03-10$ \\
$\mathrm{~T} 4$ & $47 \times 46$ & 0.216 & $09-03-10$ \\
$\mathrm{~T} 5$ & $49 \times 49$ & 0.240 & $23-02-10$ \\
$\mathrm{~T} 6$ & $55 \times 55$ & 0.303 & $17-02-10$ \\
$\mathrm{~T} 7$ & $50 \times 50$ & 0.250 & $21-02-10$ \\
\hline
\end{tabular}

Soil samples were taken from all the selected farmers field at an incremental depth of $150 \mathrm{~mm}$ from the soil surface to a depth of $600 \mathrm{~mm}(0-15 \mathrm{~cm}, 15-30 \mathrm{~cm}, 30-45 \mathrm{~cm}$, and $45-60 \mathrm{~cm})$. The samples were taken to the laboratory for the determination of field capacity and wilting point using pressure membrane apparatus at $0.3 \mathrm{~atm}$ and $15 \mathrm{~atm}$ respectively as reported by Michael, (1978). The textural analysis used was sieve hydrometer methods using standard procedures as described by Love day, (1974). The general characteristics of each of the farmers field are presented in Table 1. 


\section{Sample Size and Sampling Techniques of The Farmers Plots}

Seven (7) farms were randomly selected for the study out of about fouty five (45) farms. The farms were identified as plots T1, T2...T7. Twelve (12) measurement points per farmer plot were used for soil moisture measurements. The measurement points were randomly selected across each farmers plot. For each of the measurement points, moisture content were determined at varying incremental depths. As reported, tomato was observed to have a deep rooting habit (Doorenbos and Kassam, 1979), with an effective root zone depth of $600 \mathrm{~mm}$ (Mudiare and Kwayas, 1995). Therefore, the soil samples were taken at $150 \mathrm{~mm}$ incremental depths to a depth of $600 \mathrm{~mm}$.

\section{Description of Farmers' Field and Activities}

The experimental set-up essentially consisted of the selected farmers' irrigation plots. The farmers prepared their land by clearing and burning the farm debris. They followed it with wild flooding of the entire farm, followed by making of furrows using animal plough traction. Thereafter, the furrows were then shortened into 2- 3m length to form blocks of furrows. Each block averagely consists of ten furrows. Transplanting was preceded with the irrigation of the blocks of furrows. Usually as they irrigate, they transplant the seedlings (Table 2.1). The transplanting was done both in the early morning hours and at late evening hours. After transplanting, irrigation was carried out 3 days later which is immediately followed by mild fertilizer application. Compound fertilizers (NPK and Urea) in equal proportions are mixed in the ratio $25 \mathrm{~kg}$ NPK $(15: 15: 15)$ with $25 \mathrm{~kg}$ Urea and applied for a quarter of a hectare. This is usually the first dose. During the fertilizer application, the farmers usually apply a handful at the base of the tomato plant and covered it with soils in some cases and at times left uncovered.

Source of water for the irrigation was through tube wells/wash bore that was dug in the river beds and water was lifted from the tube wells using a $6.5 \mathrm{hp}(4.8 \mathrm{~kW})$ petrol engine pumps

$\mathrm{Q}=\mathrm{V} / \mathrm{t}$

Where:

$$
\begin{aligned}
& \mathrm{Q}=\text { Discharge, } \mathrm{m}^{3} / \mathrm{s} \\
& \mathrm{t}=\text { Time, } \mathrm{sec} \\
& \mathrm{V}=\text { Volume of container, litres }
\end{aligned}
$$$$
\text { Irrigation }(\mathrm{IRR})=\mathrm{Q} \times \mathrm{t}
$$

Where ' $Q$ ' is in $\mathrm{m}^{3} / \mathrm{s}$, and ' $\mathrm{t}$ ' in secs,Irrigation (IRR) would be in $\mathrm{m}^{3}$

Irrigation (IRR) depth basis $=\frac{Q x t}{A} \times 1000$ ... (3)

Irrigation $(I R R)_{\text {depth basis }}=$ irrigation water applied in equivelent average depth, $\mathrm{mm}$ (commonly use pump in the area) and conveyed through 2" PVC pipes to the farm inlet. Irrigation water conveyed through PVC pipes to the desired inlet point within the farm was then distributed by gravity flow through small earthen channels to irrigate all the furrows in all the plots during the study. This process was maintained throughout the growing season in all the selected farmers' plots.The farmers used varying indices to judge the timing of irrigation. Some relied on cracking of the soil surface; others depend on folding of the leaves of their crops, while others simply determined the need for irrigation shortly after water dried off from the soil surface.

In Pampaida MV, the farmers irrigate their crops mostly every four days (averagely twice every ten days). According to Mofoke et al., (2002), for most small holder farmer's water application is done at intervals based on the farmers' judgments, not necessarily backed by any scientific principle.

\section{Measurement of Irrigation Water}

The pump discharges for each farmer was estimated with the use of a 55litre barrel plastic container and stopwatch. Irrigation water was discharged into the known volume container and timed with a stopwatch to know the time it takes to fill the container. This was repeated 5 times to come up with approximate average pump discharge for each farmer.

The irrigation water applied (IRR) at each irrigation was computed from average pump discharge $(\mathrm{Q})$ and application time (t) using Enq. 2. \& 3 respectively. By measuring the pump discharge $(\mathrm{Q})$ and application time $(\mathrm{t})$, the total quantity of water applied during irrigation was estimated (James, 1988). The farmers measured their application time themselves with wristwatches after being educated on the procedure and necessary precautions to reckon with.

Now, to express IRR on depth basis rather than volume basis, equation 3 was used to obtained the irrigation water on depth basis. That is, since

$\mathrm{A}=$ average farm area $\mathrm{m}^{2}$

Reference Crop Evapotranspiration

An average of 10 year weather data was used, to determine the reference crop evapotranspiration (ETo) using the Hargreaves equation (Eqn. 4). The weather data was obtained at the Institute for Agricultural Research (IAR), Ahmadu Bello University, Samaru Zaria. The data were temperature, sunshine, relative humidity and wind speed.

The Hargreaves ETo Equation expressed as :

$E T_{O}=0.0023\left(\mathrm{~T}_{\text {mean }}+17.8\right)\left(\mathrm{T}_{\max }-\mathrm{T}_{\text {Min }}\right)^{0.5} \mathrm{R}_{\mathrm{a}}$

Where:

$\mathrm{T}_{\max }=$ daily maximum air temperature $\left({ }^{\circ} \mathrm{c}\right)$

$\mathrm{T}_{\min }=$ daily minimum air temperature $\left({ }^{\circ} \mathrm{c}\right)$

$\mathrm{T}_{\text {mean }}=$ mean of the daily maximum and minimum air temperatures.

$\mathrm{Ra}=$ extra terrestrial radiation for daily periods $\left(\mathrm{MJm}^{-2} \mathrm{day}^{-1}\right)$ as detailed by Allen et al (1998).

Calibration of Gypsum Blocks 
Soil samples were collected from various depths for gravimetric moisture content determination (Brady and Weil, 1999). Installation of gypsum blocks were done by soaking the blocks in water for about five minutes to saturate the blocks. Four small diameter holes were made in each measurement point representing depths of $15,25,40$ and $55 \mathrm{~cm}$ with the use of auger. Resistance readings were taken with the aid of an electrical resistance meter connected to the electrode of the gypsum blocks. Measurement made at depth 15, 25,40 and $55 \mathrm{~cm}$ below the soil surface represent soil profile depth of $0-15$, $15-30$ and $30-45 \mathrm{~cm}$ and $45-60 \mathrm{~cm}$ respectively.

Regression analysis was done on volumetric moisture content from gravimetric method on the ordinate axis and their corresponding resistance values indicated by the resistance meter reading on the abscissa axis at various depths. The calibration curve and the regression model equation was thus obtained.

\section{Measurement of Soil Moisture}

The farmers generally observed four days irrigation intervals. Soil moisture content measurement were carried mostly twice in ten days, according to the farmer's irrigation practice, throughout the growing season.

\section{Determination of Actual Crop Evapotranspiration.}

Crop evapotranspiration $\left(\mathrm{ET}_{\mathrm{a}}\right)$ is an empirical estimate of the total amount of water required for a crop growing in an area under known climate conditions so that crop production is not limited by lack of water. The actual crop evapotranspiration was calculated from measured soil moisture content data obtained using gypsum blocks as outlined by Michael (1979). The average daily actual evapotranspiration expressed was calculated using Eqn. 5.

$$
E T_{a}=\sum_{i=1}^{n} \frac{M_{1 i}-M_{2 i}}{100} \times B d_{i} D_{i}
$$

Where:

$\mathrm{ET}_{\mathrm{a}}$ is actual crop evapotranspiration $\mathrm{mm} /$ day

$\mathrm{M}_{1}$ is the gravimetric moisture content $(\mathrm{g} / \mathrm{g})$ at the first sampling in the ith layer

$\mathrm{M}_{2}$ is the gravimetric moisture content $(\mathrm{g} / \mathrm{g})$ at the second sampling in the ith layer

Di is the depth of ith layer (mm); $n$ is the number of depth within the soil profile

Bdi is the specific gravity of the soil layer

\section{Water Application Efficiency}

The water application efficiency as reported by Michael, (1972) was calculated as the ratio of the average depth of irrigation water infiltrated and stored in the root zone to the average depth of irrigation water applied, expressed as a percentage.

\section{Distribution Uniformity}

The distribution uniformity was computed as ratio expressed in percent, of average low-quarter amount infiltrated (average of lowest 3 catches) to the average amount infiltrated (average of the catches of the 12 sampling points) for each irrigation event.

\section{Determination of Crop Water Use}

Crop water use efficiency (CWUE) is commonly expressed as the economic yield divided by the seasonal crop water use (seasonal evapotranspiration) (Flenet et al. 1996; Karam et al. 2007). The water use efficiency was calculated on the basis of marketable product since this is of fundamental concern to the farmers. The crops were observed to be grown entirely under irrigation as there was no contribution of water from precipitation.

\section{Adequacy of Irrigation}

Adequacy of irrigation was determined through a frequency distribution plot of infiltrated depths against cumulative percent area. The infiltrated depths were plotted on the vertical axis against the cumulative percent area on the horizontal axis, to generate a curve of infiltrated depth against cumulative percent area. Adequacy of irrigation was then read off from the curve as the cumulative percent area at the infiltrated depth equal to the moisture depleted for the specific irrigation.

\section{Agronomic Practices}

All the selected farmers in this study planted tomato crop (Lycopersicum esculentum, Mill) seeds of variety UC82B in their nurseries. The bed was well tilled and rows of $20 \mathrm{~cm}-25 \mathrm{~cm}$ marked out along the bed. Then a groove of $1.5-2 \mathrm{~cm}$ deep was made along the row and the seeds were sown, then covered lightly with soil and the bed watered. The bed was covered with straw until germination starts. After germination has taken place, the straw was removed. The tomato seedlings were transplanted after about 32-35days of nursery across the seven farmers plots. Due to the varying dates of the nurseries, the transplanting dates also vary among the seven selected farmers. Weeding was done manually using hoes at different dates. It was done approximately two times by each farmer from transplanting to harvesting stage. Two days after the first weeding they applied a full dose of fertilizer. Before the application, they mixed 1 bag of $25 \mathrm{~kg}$ NPK $(15: 15: 15)$ with $1 / 2$ bag of $25 \mathrm{Kg}$ Urea for a quarter of a hectare size farm.

The plants were sprayed with cypermethrin insecticides and Mancozeb fungicide against White flies (Bemicia tabaci), fruit wors and other pests which were noticed on the entire selected field, especially during fruiting and they use various dosage of the insecticides to spray the crops. The insecticide and fungal spray was done at the same time by mixing them together and spraying with a 16 liter size knapsack spray. The ratio of mixing was 1 liter/ha insecticide (cypermethrin), mixed with about $100 \mathrm{gm}$ of fungal powder (Mancozeb) and sprayed with a 16 liter knapsack spray.

Ripening of fruits became evident when the fruit started turning yellow and eventually red 65-70days after transplanting across the selected plots. Fruits were harvested separately in baskets and weigh, each time harvesting was done. Harvesting was done manually using hand picking and the period of harvesting lasted between four to six weeks across the assessed farmer's plots.

\section{Statistical Analysis.}

Crop data obtained were AE, DU, AI, and CWUE, however, for the tomato crop, were weighed to find the total yield per plot for all the selected farmers were collected and subjected to statistical analysis of variance and the significance among treatment means was evaluated with Duncan's Multiple Range Test to check significant differences between the treatments (SPSS, 2017).

\section{RESULTS AND DISCUSSION}

The performance of the various amount of water applied were based on quantitative analyses. The parameters considered include: Water applied, crop water use and tomato yield. Average tomato yield for various amount of water applied in 
terms of how much water was utilized were determined and compared.

\section{Soil Physical Properties}

Table 2a: Soil Physical Properties for Plot T1
The soil physical properties for plots of each farmers are presented in Table $2(\mathrm{a}-\mathrm{g})$, from the soil physical properties of plots $\mathrm{T} 1 \ldots \mathrm{T} 7$ showed that there was not much variation within the selected farms in the study area. The soil of the experimental site is predominantly sandy loam. All the soils were found to be of a homogenous profile within the $0-600 \mathrm{~mm}$ depth.

\begin{tabular}{lccccc}
$\begin{array}{l}\text { Soil depth } \\
(\mathrm{mm})\end{array}$ & $\begin{array}{c}\text { Soil texture } \\
\text { Class }\end{array}$ & $\begin{array}{c}\text { FC } \\
(\% \text { by weight })\end{array}$ & $\begin{array}{c}\text { PWP } \\
(\% \text { by } \\
\text { weight })\end{array}$ & $\begin{array}{c}\text { Bulk } \\
\text { density } \\
\text { g/cm3 }\end{array}$ & $\begin{array}{c}\text { TAWC } \\
(\% \text { Vol. basis })\end{array}$ \\
\hline $0-150$ & Sandy Loam & 36.6 & 26.0 & 1.50 & 15.98 \\
$150-300$ & Sandy Loam & 30.3 & 22.8 & 1.75 & 13.18 \\
$300-450$ & Sandy Loam & 32.7 & 22.6 & 1.53 & 15.45 \\
$450-600$ & Sandy Loam & 36.6 & 23.6 & 1.53 & 19.91 \\
\hline
\end{tabular}

Table 2b: Soil Physical Properties for Plot T2

\begin{tabular}{|c|c|c|c|c|c|}
\hline $\begin{array}{l}\text { Soil depth } \\
(\mathrm{mm})\end{array}$ & $\begin{array}{l}\text { Soil } \\
\text { texture } \\
\text { Class }\end{array}$ & $\begin{array}{c}\text { FC } \\
\text { (\%by weight) }\end{array}$ & $\begin{array}{c}\text { PWP } \\
\text { (\% by weight) }\end{array}$ & $\begin{array}{c}\text { Bulk } \\
\text { density } \\
\text { g/cm3 }\end{array}$ & $\begin{array}{c}\text { TAWC } \\
\text { (\% Vol. } \\
\text { basis) }\end{array}$ \\
\hline $0-150$ & $\begin{array}{l}\text { Sandy } \\
\text { Loam } \\
\text { Sandy }\end{array}$ & 24.7 & 12.2 & 1.83 & 22.88 \\
\hline $150-300$ & $\begin{array}{l}\text { Loam } \\
\text { Sandy }\end{array}$ & 21.6 & 15.1 & 1.77 & 11.51 \\
\hline $300-450$ & $\begin{array}{l}\text { Loam } \\
\text { Sandy }\end{array}$ & 25.3 & 17.9 & 2.21 & 16.35 \\
\hline $450-600$ & Loam & 27.2 & 20.2 & 1.76 & 12.32 \\
\hline
\end{tabular}

Table 2c: Soil Physical Properties for Plot T3

\begin{tabular}{llcccc}
\hline $\begin{array}{l}\text { Soil depth } \\
(\mathrm{mm})\end{array}$ & $\begin{array}{c}\text { Soil texture } \\
\text { Class }\end{array}$ & $\begin{array}{c}\text { FC } \\
(\% \text { by weight })\end{array}$ & $\begin{array}{c}\text { PWP } \\
(\% \text { by weight })\end{array}$ & $\begin{array}{c}\text { Bulk } \\
\text { density } \\
\text { g/cm3 }\end{array}$ & $\begin{array}{c}\text { TAWC } \\
\text { Vol. basis })\end{array}$ \\
\hline $0-150$ & Sandy Loam & 36.1 & 19.2 & 1.57 & 26.53 \\
$150-300$ & Sandy Loam & 24.0 & 11.2 & 1.22 & 15.62 \\
$300-450$ & Sandy Loam & 36.7 & 21.7 & 1.30 & 19.62 \\
$450-600$ & Sandy Loam & 45.0 & 28.3 & 1.33 & 22.21 \\
\hline
\end{tabular}

Table 2d: Soil Physical Properties for Plot T4

\begin{tabular}{llcccc}
\hline $\begin{array}{l}\text { Soil depth } \\
(\mathrm{mm})\end{array}$ & $\begin{array}{c}\text { Soil texture } \\
\text { Class }\end{array}$ & $\begin{array}{c}\text { FC } \\
(\% \text { by weight })\end{array}$ & $\begin{array}{c}\text { PWP } \\
(\% \text { by weight })\end{array}$ & $\begin{array}{c}\text { Bulk } \\
\text { density } \\
\text { g/cm3 }\end{array}$ & $\begin{array}{c}\text { TAWC } \\
\text { Vol. basis })\end{array}$ \\
\hline $0-150$ & Sandy Loam & 31.4 & 17.7 & 1.37 & 18.77 \\
$150-300$ & Sandy Loam & 22.6 & 9.8 & 1.48 & 18.94 \\
$300-450$ & Sandy Loam & 21.3 & 8.0 & 1.48 & 19.68 \\
$450-600$ & Sandy Loam & 18.4 & 6.9 & 1.37 & 15.76 \\
\hline
\end{tabular}


Table 2e: Soil Physical Properties for Plot T5

\begin{tabular}{llcccc}
\hline $\begin{array}{l}\text { Soil depth } \\
(\mathrm{mm})\end{array}$ & $\begin{array}{c}\text { Soil texture } \\
\text { Class }\end{array}$ & $\begin{array}{c}\text { FC } \\
(\% \text { by weight })\end{array}$ & $\begin{array}{c}\text { PWP } \\
(\% \text { by weight })\end{array}$ & $\begin{array}{c}\text { Bulk } \\
\text { density } \\
\text { g/cm3 }\end{array}$ & $\begin{array}{c}\text { TAWC } \\
\text { Vol. basis })\end{array}$ \\
\hline $0-150$ & Sandy Loam & 32.0 & 20.0 & 1.43 & 17.16 \\
$150-300$ & Sandy Loam & 30.7 & 20.3 & 1.33 & 13.83 \\
$300-450$ & Sandy Loam & 35.5 & 25.5 & 1.41 & 14.10 \\
$450-600$ & Sandy Loam & 34.6 & 23.8 & 1.46 & 15.77 \\
\hline
\end{tabular}

Table 2f: Soil Physical Properties for Plot T6

\begin{tabular}{llcccc}
\hline $\begin{array}{l}\text { Soil depth } \\
(\mathrm{mm})\end{array}$ & $\begin{array}{c}\text { Soil texture } \\
\text { Class }\end{array}$ & $\begin{array}{c}\text { FC } \\
(\% \text { by weight })\end{array}$ & $\begin{array}{c}\text { PWP } \\
\text { (\% by weight })\end{array}$ & $\begin{array}{c}\text { Bulk } \\
\text { density } \\
\text { g/cm3 }\end{array}$ & $\begin{array}{c}\text { TAWC } \\
\text { (\% Vol. basis })\end{array}$ \\
\hline $0-150$ & Sandy Loam & 36.6 & 26.0 & 1.50 & 15.98 \\
$150-300$ & Sandy Loam & 30.3 & 22.8 & 1.75 & 13.18 \\
$300-450$ & Sandy Loam & 32.7 & 22.6 & 1.53 & 15.45 \\
$450-600$ & Sandy Loam & 36.6 & 23.6 & 1.53 & 19.91 \\
\hline
\end{tabular}

Table 2g: Soil Physical Properties for Plot T7

\begin{tabular}{llcccc}
\hline $\begin{array}{l}\text { Soil depth } \\
(\mathrm{mm})\end{array}$ & $\begin{array}{c}\text { Soil texture } \\
\text { Class }\end{array}$ & $\begin{array}{c}\text { FC } \\
(\% \text { by weight })\end{array}$ & $\begin{array}{c}\text { PWP } \\
(\% \text { by weight })\end{array}$ & $\begin{array}{c}\text { Bulk } \\
\text { density } \\
\text { g/cm3 }\end{array}$ & $\begin{array}{c}\text { TAWC } \\
\text { Vol. basis })\end{array}$ \\
\hline $0-150$ & Sandy Loam & 24.7 & 15.4 & 1.83 & 17.02 \\
$150-300$ & Sandy Loam & 21.6 & 10.8 & 1.77 & 19.12 \\
$300-450$ & Sandy Loam & 29.2 & 20.4 & 2.21 & 19.45 \\
$450-600$ & Sandy Loam & 34.0 & 23.3 & 1.76 & 18.83 \\
\hline
\end{tabular}

\section{Calibration of Gypsum Blocks}

The calibration equation provides a clear interpretation of soil moisture content value for a given resistance value. The gypsum blocks calibration relationship of soil moisture content and electrical resistance reading was found to be :

$$
\mathrm{Y}=124.0 \mathrm{X}^{-0.27}
$$

The coefficient of determination was obtained as 0.9370 , this expression was used to estimate the soil moisture content $(\mathrm{Y})$ when the resistance reading $(\mathrm{X})$ is known.

\section{Water Application}

Each of the selected farmer abstracts irrigation water using a water pump through a 2 " size rubber horse pipe from a combination of tube wells in the riverbeds. PVC pipes were then used to convey water to the plots. Irrigation water conveyed through PVC pipes to the desired inlet point within the farm was then distributed by gravity flow to irrigate all the furrows as presented in Table 3. This process was maintained throughout the growing season in all the selected (assessed) farmers' plots. Irrigation Characteristics at the Study Area

Table 3 shows number of irrigations per season, seasonal averages of irrigation interval, pump discharge, application time and average depth of water applied per irrigation for all the selected plots. The seasonal averages were computed from the field data.

Similarly, Table 3 shows that the assessed farmer's plots were irrigated with a pump discharge ranging between $4.01 / \mathrm{s}$ to $4.61 / \mathrm{s}$ and the water application time also varies between $5 \mathrm{hrs} 6 \mathrm{mins}$ to 6 hrs 2 mins. The seasonal ranges of average application depth per irrigation were found to be between $32-44 \mathrm{~mm}$. It was also observed that majority of the farmers (T2, T3,T5 \& T6) did reduce their irrigation application time at some point as the season progresses, even though marginally, which did not translate into any significant reduction in the amount of water applied per irrigation.Also, due to the relative locations of the farms to each other, different pumping heads and possible pump conditions may have contributed to the varying pump discharges. Stegman (1980) noted that high frequency irrigation is generally undesirable for gravity irrigation systems.

Therefore the farmers should be discouraged from this practice, not only because it may lead to excessive deep percolation loss, but also it may cause leaching of the small quantities of fertilizers applied by the farmers. 
Table 3: Seasonal average values of irrigation interval, pump discharge, application time, and depth of water applied for the assessed farmer's plots $\mathrm{T} 1, \mathrm{~T} 2 \ldots \mathrm{T} 7$

\begin{tabular}{cccccc}
\hline Plot & $\begin{array}{c}\text { No of } \\
\text { Irrigation }\end{array}$ & $\begin{array}{c}\text { Irrigation } \\
\text { interval (days) }\end{array}$ & $\begin{array}{c}\text { Pump } \\
\text { discharge } \\
(1 / \mathrm{sec})\end{array}$ & $\begin{array}{c}\text { Application time } \\
(\mathrm{hrs})\end{array}$ & $\begin{array}{c}\text { Average depth of water } \\
\text { Applied/irrigation } \\
(\mathrm{mm})\end{array}$ \\
\hline & 16 & & & & \\
T1 & 16 & 4 & 4.5 & 6.2 & 44 \\
T2 & 16 & 4 & 4.1 & 5.6 & 36 \\
T3 & 16 & 5 & 4.5 & 5.6 & 37 \\
T4 & 16 & 4 & 4.0 & 5.7 & 36 \\
T5 & 16 & 4 & 4.6 & 5.6 & 32 \\
T6 & 16 & 4 & 4.6 & 5.9 & 37 \\
T7 & 16 & & & 5.6 & \\
\hline
\end{tabular}

Table 4 shows the irrigation activities, it was observed that the plots were irrigated with average irrigation interval of 4-5 days. It was also observed that there was not much difference between the irrigation intervals at the initial stage of the crop growth and throughout the remaining growth stages. This implied that the farmers were maintaining the same irrigation intervals throughout the four growth stages of the tomato crop in all the selected crops. It also means that all the plots were operated on similar frequency of irrigation.

The farmers were irrigating about twice every ten days throughout the growing season. This may be based on their presumption that the more water they apply the higher the crop yield. It was also observed, through interaction, that the few situations in which some farmers extended their irrigation interval beyond four days was actually based on some external factors beyond their control like pump break downs, fuel scarcity and the inability to procure fuel in good time which makes some farmers to reschedule their irrigation interval. 
Table 4: Water application depth $(\mathrm{mm})$ per irrigation for the season

\begin{tabular}{|c|c|c|c|c|c|c|c|c|c|c|c|c|c|c|c|c|c|}
\hline Plot & $1^{\text {st }}$ & $2^{\text {nd }}$ & $3^{\text {rd }}$ & $4^{\text {th }}$ & $5^{\text {th }}$ & $6^{\text {th }}$ & $7^{\text {th }}$ & $8^{\text {th }}$ & $9^{\text {th }}$ & $10^{\text {th }}$ & $11^{\text {th }}$ & $12^{\text {th }}$ & $13^{\text {th }}$ & $14^{\text {th }}$ & $15^{\text {th }}$ & $16^{\text {th }}$ & Total \\
\hline T1 & 43 & 43 & 44 & 44 & 43 & 44 & 44 & 44 & 44 & 43 & 45 & 45 & 45 & 43 & 45 & 44 & 703 \\
\hline $\mathrm{T} 2$ & 47 & 47 & 47 & 45 & 42 & 38 & 38 & 37 & 37 & 37 & 37 & 40 & 39 & 38 & 37 & 36 & 642 \\
\hline $\mathrm{T} 3$ & 39 & 39 & 40 & 35 & 36 & 34 & 35 & 34 & 35 & 34 & 33 & 39 & 35 & 34 & 34 & 34 & 570 \\
\hline $\mathrm{T} 4$ & 38 & 38 & 36 & 32 & 32 & 32 & 32 & 31 & 31 & 32 & 31 & 31 & 37 & 32 & 36 & 36 & 537 \\
\hline T5 & 43 & 43 & 40 & 35 & 33 & 33 & 35 & 32 & 34 & 32 & 32 & 31 & 37 & 35 & 36 & 35 & 566 \\
\hline T6 & 34 & 34 & 32 & 33 & 30 & 30 & 29 & 30 & 30 & 31 & 32 & 28 & 31 & 30 & 29 & 29 & 492 \\
\hline $\mathrm{T} 7$ & 39 & 39 & 39 & 36 & 35 & 35 & 35 & 33 & 34 & 35 & 34 & 33 & 39 & 35 & 39 & 35 & 575 \\
\hline
\end{tabular}


Determination of Irrigation System Performance

Table 5 shows Seasonal values of application efficiency (AE), Distribution uniformity (DU) and Adequacy of irrigation (AI) for the selected assessed farmers' plots which quantitatively describes the desired effectiveness of irrigation that maximizes net farm profit. The seasonal average were computed from the field data set.

Table 5 shows all the selected plots had an average seasonal AE in the range of 74 to $92 \%$, DU in the range of 72 to $89 \%$, and AI in the range of 63 to $92 \%$. Similarly, the highest AE was obtained in plot T6 (92\%) and the highest DU and AI obtained in plots T3 (89\%) and T7 (92\%) respectively. Irrigation with highest AE, DU, \& AI are not always desirable, since they do not always maximize net farm profit. Whereas the lowest AE (74\%), DU (72\%) and AI (63\%) occurred in plot T1. It was also observed from Table 4 that all the selected plots were operated with application efficiencies above $60 \%$. A well designed and properly managed surface system can attain efficiencies of $60 \%$ or better (James, 1988).

Table 5: Seasonal values of AE, DU and AI of irrigation for the selected plots T1, T2...T7

\begin{tabular}{|c|c|c|c|c|}
\hline Plot & Application efficiency & $(\%)$ & Distribution uniformity (\%) & Adequacy of irrigation (\%) \\
\hline $\mathrm{T} 1$ & 74 & & 72 & 63 \\
\hline $\mathrm{T} 2$ & 86 & & 74 & 88 \\
\hline $\mathrm{T} 3$ & 88 & & 89 & 87 \\
\hline $\mathrm{T} 4$ & 91 & & 75 & 82 \\
\hline T5 & 89 & & 77 & 91 \\
\hline T6 & 92 & & 73 & 75 \\
\hline $\mathrm{T} 7$ & 88 & & 77 & 92 \\
\hline
\end{tabular}

The results also revealed that water distribution uniformity and adequacy of irrigation were above $70 \%$ and $60 \%$ respectively in all the selected plots. Distribution uniformity is the most commonly used uniformity index in surface irrigation application. Even though the DUs are better than the value of $70 \%$ reported by Pitts et al. (1996) in the irrigations systems of Western United States, they fall outside the acceptable limits, which was set by FAO to be $80 \%$ (FAO, 1989). High adequacy of irrigation is often associated with enormous wastage especially for gravity irrigation systems. This was another indication that the farmers were over irrigating in most of the periods. An effective irrigation practice, according to James (1988), is one that offers the best combination of Application efficiency, Distribution Uniformity and Adequacy of Irrigation that maximizes farm profits rather than simply maximizing the performance parameters. Maximizing performance parameters provided a poor basis for managing an irrigation system to optimal profit or any other value such as production per unit of energy input. This was reported by Keller et al., (1980).

\section{Seasonal Irrigation Water Use, Crop Water Use and Crop Yield}

Crop water use is an important parameter in crop production under irrigation. The water utilization by crop is generally described in terms of crop water use efficiency (CWUE). CWUE can be taken as a factor used for assessing either the total dry matter production of crop (in economic terms) or the proportion of dry matter production harvested as economic yield through the use of water in form of evapotranspiration. The number of irrigations per season, seasonal irrigation water applied, seasonal crop water use, crop water use efficiency, and measured crop yield for all the selected plots are presented in Table 6.

Table 6: Seasonal irrigation water use, Crop water use, Crop yield and Crop water use efficiency of irrigated Tomato crop for the 2009/2010 dry season.

\begin{tabular}{llllll}
\hline Plots & $\begin{array}{l}\text { No. of } \\
\text { irrigations }\end{array}$ & $\begin{array}{l}\text { IWU } \\
\mathrm{mm} / \text { Season }\end{array}$ & CWU mm/Season & $\begin{array}{l}\text { Crop yield } \\
\text { (t/ha) }\end{array}$ & $\begin{array}{l}\text { CWUE (Kg/ha- } \\
\mathrm{mm})\end{array}$ \\
\hline T1 & 16 & 703 & 355 & 22.3 & 62.8 \\
T2 & 16 & 642 & 399 & 16.6 & 41.6 \\
T3 & 16 & 570 & 396 & 19.6 & 48.7 \\
T4 & 16 & 537 & 443 & 18.6 & 42.0 \\
T5 & 16 & 566 & 399 & 19.2 & 48.1 \\
T6 & 16 & 492 & 369 & 19.7 & 53.4 \\
T7 & 16 & 575 & 412 & 20.2 & 49.0 \\
\hline
\end{tabular}


From Table 3.5, it can be deduced that the tomato yield harvested and measured was between 16.6 to $22.3 \mathrm{t} / \mathrm{ha}$, with seasonal crop water use ranging from $355 \mathrm{~mm} / \mathrm{season}$ to 443 $\mathrm{mm} / \mathrm{season}$.Plot $\mathrm{T} 2$ had the lowest crop yield of $16.6 \mathrm{t} / \mathrm{ha}$ with seasonal crop water use of $399 \mathrm{~mm} / \mathrm{season}$. The maximum yield recorded was $22.3 \mathrm{t} / \mathrm{ha}$ from plot $\mathrm{T} 1$, with a corresponding seasonal crop water use of $355 \mathrm{~mm} / \mathrm{season}$. According to Doorenbos and Kassam (1979), tomato grown under good management practices could consume as much as $400-600 \mathrm{~mm}$ of water, giving yields of 45-65 t/ha. Earlier reports (IAR, 1994) also indicate the possibility of attaining up to $40 \mathrm{t} / \mathrm{ha}$ for tomato grown under irrigation in the Guinea Savanna Zone of Nigeria. This shows that there is the possibility of increasing the crop yield beyond the $22.3 \mathrm{t} / \mathrm{ha}$ when the agronomic practices and the irrigation water management are improved. The factors that contribute to higher yield in crop production are root growth and soil environmental conditions, which sometimes soil temperature influences. Higher soil temperature, in arid and semi arid regions,is experienced in the rootzone during dry season farming and was found to be an important factor adversely affecting root and shoot growths, dry matter production and subsequent yields of the crop, (Gupta and Gupta 1983). Also, the observed variations in seasonal water use as shown in Table 6 indicate that the irrigation practice was highly variable in terms of water application regimes. The irrigation water applied ranges from $492 \mathrm{~mm} / \mathrm{season}$ to $703 \mathrm{~mm} / \mathrm{season}$, with plot T5 having the lowest and plot T1 recording the highest respectively. The length of the growing season was not the same due to different agronomic practices. This may have contributed to the unequal amounts of moisture consumed by the crops in the selected farms.

Furthermore, Table 6 shows the crop water use efficiencies (CWUE) for selected plots in the study area. The crop water use efficiency was used to assess the performance of an irrigation practice in terms of crop yield produced at least possible water consumed. It can be seen from Table 6 that Plot T1 gave the highest crop yield water use of $63 \mathrm{Kg} / \mathrm{ha}-\mathrm{mm}$ and a seasonal consumptive use of $355 \mathrm{~mm}$. Previous reports by Omotowoju (1992) points out that an irrigation schedule that would reduce consumptive use whilst maintaining yield reduction at the bearest minimum would generally improve CWUE of agricultural crops. However, none of the farms appear to have efficiently utilized irrigation water for production of marketable crop yield. This is so because their CWUE's falls below the FAO range of 100 to $120 \mathrm{~kg} / \mathrm{ha}-\mathrm{mm}$ for tomato as reported by Doorenbos and Kassam (1986). Similarly, Mofoke (2000) reported a range of 27 to $123 \mathrm{~kg} / \mathrm{ha}-\mathrm{mm}$ for eight Fadama farms in Samaru, Zaria and also, Othman (2001) reported a CWUE of $71.16 \mathrm{~kg} / \mathrm{ha}-\mathrm{mm}$ in Bauchi.

\section{CONCLUSION}

Evaluation of Farmers Practice within Pampaida Millennium Village was evaluated, a total of 7 tomato farmers were selected out of 45 farmers for the assessment exercise, in this research reported herein, in terms of crop water use efficiency and effectiveness of irrigation; it can be concluded that, for irrigation of a Tomato field, water application depth should be within $42 \mathrm{~mm}$ for Tomato in Pampaida Millennium Village. Furthermore, to avoid over irrigation at the initial and late crop growth stage for Tomato crop, farmers should apply water less $42 \mathrm{~mm}$ in Pampaida Millennium Village.

\section{REFERENCES}

Brady,N.C and R.R. Weils.(1999).The Nature and Properties of Soils.14th Edition.Pearson Education

Doorenbos, J. and Kassam A.H. (1979); Yield response to water.Irri. Drain. Paper 33.FAO,Rome, Italy.

Doorenbos, J. and Kassam A.H. (1986); Yield response to water. FAO Irri. And Drain. Paper No. 33. (Revised Ed.),Rome, Italy.

Fagade,S.O. (1997). Yield evolution at irrigated schemes in Nigeria. Food and agricultural

Organization of the United Nations, Rome.

FAO, (1989). Guidelines for Designing and Evaluating Surface Irrigation System: Irrigation and Drainage Paper.No.45. FAO, Rome.

FAO,(2002).Deficit irrigation practices. Water Report No.22,Rome.

Flenet, F, A. Bouniols, C. Saraiva, (1996): Sunflower response to a range of soil moisture

Content.Euro J Agron 5:161-167

Graham, A.H., Decoteau D.R., linvill D.E (1995).Development of a polyethene mulch system that changes colour in the field.Hort.Sci.,30;265-9

Gupta J.P. and Gupta G.N. (1983) "Effects of grass mulching on growth and yield of legumes" J. of Agric. Water Mgnt.6:375-383

Institute for Agricultural Research (IAR) Samaru, Nigeria.199394 Research Progress Report

James,L.G.(1988).Principles of farm Irrigation System Design.John wiley and Sons, New

York,N.Y.

Karam,F,Lahoud R; R. Kabalam; J. Breidi; C. Chalita; Y. Rouphael (2007).Evapotranspiration, seed yield and water use efficiency of drip irrigated sunflower under full and deficit irrigation conditions.Agric Water Manage 90:213-223

Keller,J.,F.Corey,W.R Walker and M.E. Vavra.(1980).Evaluation of irrigation systems.In:Irrigation Challenges of the 80's.Proc. of the 2nd Nat. Irri.

Symp.,Nebraska.ASAE.St. Joseph, Michigan: 95-105.

Kirda,C.(2002). Deficit Irrigation Scheduling based on plant growth stages showing water stress tolerance In: Deficit irrigation practice. Water reports 22.FAO, Rome, pp.1-3

Loveday, J (1974) Method for analysis of irrigation soils.Tech. Communication,no.45 of commonwealth Bureau of Soils. Australia. 
Michael,A.M. ,S Mohan and K.R. Swanithan (1972); Design and Evaluation of Irrigation methods. IARI,Pub,New Delhi, India

Michael, A.M 1978. Irrigation, theory and practice. Vani Educational Books, India.

Michael,A.M 1979. Irrigation, theory and practice.Vani Educational Books,India

Mofoke, A.L.E, 2000.Performance evaluation of Fadama Irrigation practice. Unpublished

M.Sc thesis research work, Dept of Agric. Engineering, A.B.U. Zaria

Mofoke ALE, Ahmed A, Mudiare OJ (2002). Evaluation of Fadama Irrigation Efficiencies around Samaru, Zaria, Nigeria. J. Agri. Environ., 3(2): 319-329

Mudiare, O.J and S.T.Kwayas .1995.Soil moisture extraction pattern for irrigated tomato. Proc. Nig. Soc. Agric. Engrs.Vol.17: 140-153.

National Population Commission, (2006).National and State population and Housing Table:CensuspriorityTableVol.I.http://www.population.gov.ng /index.php/publications/138-national-and- state-populationand-housing-tables-2006-census-priority-tables-vol-1

Omotowoju, J.S., (1992). Evaluation of crop performance under high water table conditions.

M.Sc thesis, Dept of Agric. Engineering, Ahmadu Bello University, Zaria.
Othman, M.K.(2001). "Effect of mulch on water use for some common vegetable fadama

crops In Bauchi" Unpublished M.sc Thesis, Dept. of Agricultural Engineering, ABU, Zaria, Nigeria.

Philips, D.A (1990) .Economic issues in irrigated farming in Nigeria. Farmer participation in irrigation dev. and management Proc. National workshop held at IAR,Samaru-Zaria.pp189-198.

Pitts D, Peterson K, Gilbert, G and Fastenau, R (1996). Field assessment of irrigation system performance. 12(3):307-313. American Society of Agricultural Engineers, U.S.A.

Qamar, U. and M.N. Tyem. (1994). FACU and Fadama development. Policies and experiences. Strategies for sustainable use of fadama lands in Northern Nigeria. CSER/IIED.

Sanchez P.A, Palm C.A, Sachs J.D., Denning G.L., Flor R., Zamba C.(2009). "The African Millennium Villages." Proceedings of the National Academy of Sciences 104.

Stegman, E.C., J.T. Musick and J. I. Stewart.(1980). Irrigation water Management. In: Design and Operation of Farm irrigation Systems.(M.E. Jensen,ed.) ASAE Monograph 3:763-809.

Tariq J.A. and K. Usman (2009). Regulated deficit irrigation scheduling of Maize crop.Sarhad J.Agric. 25 (3) :441-450.

World Bank, (2011). Water Resources Management. Retrieved, 10th December, 2015 from http//water.worldbank.org/water/topics/agricultural water management International license viewed via https://creativecommons.org/licenses/by/4.0/ which permits unrestricted use, distribution, and reproduction in any medium, provided the original work is cited appropriately. 